\title{
Olivet- ZAC du Larry, Zone 2
}

$\mathrm{n}^{\circ} 064492$

\section{Alain Mairesse}

\section{(2) OpenEdition}

Journals

Édition électronique

URL : http://journals.openedition.org/adlfi/14324

ISSN : 2114-0502

Éditeur

Ministère de la culture

Référence électronique

Alain Mairesse, "Olivet- ZAC du Larry, Zone 2 », ADLFI. Archéologie de la France - Informations [En ligne], Centre, mis en ligne le 20 mars 2015, consulté le 03 mai 2019. URL : http:// journals.openedition.org/adlfi/14324

Ce document a été généré automatiquement le 3 mai 2019.

(c) Ministère de la Culture et de la Communication, CNRS 


\section{Olivet- ZAC du Larry, Zone 2}

$n^{\circ} 064492$

\section{Alain Mairesse}

Lien Atlas (MCC) :

http://atlas.patrimoines.culture.fr/atlas/trunk/index.php?

ap_theme=DOM_2.01.02\&ap_bbox=1.850;47.832;1.933;47.880

1 La proximité d'un site archéologique historique aux environs du hameau actuel du Larry a été confirmée, où a pu être noté l'existence de puits d'extraction de moellons calcaire.

INDEX

Index géographique : Centre, Loiret (45), Olivet

Mots-clés : puits

operation Évaluation archéologique (EV) 